\author{
JoAnNa CAEKIEWICZ, IRENEUSz WÓJCIK \\ Morski Instytut Rybacki - Państwowy Instytut Badawczy \\ Kołłataja 1, 81-332 Gdynia \\ E-mail: jcalkiewicz@mir.gdynia.pl
}

\title{
ZASOBY DANYCH ICHTIOLOGICZNO-RYBACKICH MORSKIEGO INSTYTUTU RYBACKIEGO - PAŃSTWOWEGO INSTYTUTU BADAWCZEGO*
}

\section{NIECO HIISTORII I WSPÓŁCZESNE DZIAŁANIA}

Dokładnie 100 lat temu, w czerwcu 1921 r., powołano pierwsza polska placówkę badań morza: Morskie Laboratorium Rybackie (MLR) na Helu. Rok wcześniej Sejm Ustawodawczy w dniu historycznych zaślubin Polski z Bałtykiem, 10 lutego 1920 r. (Ryc. 1), podjał uchwałę w sprawie utworzenia „stacji naukowo-doświadczalnej dla celów oceanologiczno-rybackich nad morzem Bałtyckim". Wniosek w sprawie założenia stacji trzy dni wcześniej przedłożyli w Sejmie działacze i politycy II Rzeczpospolitej (Ryc. 2). Pomysł i zabiegi mające na celu utworzenie jednostki, która zajmowałaby się badaniami morza, były możliwe dzięki traktatowi wersalskiemu, na podstawie którego Polska otrzymała pas wybrzeża długi na prawie $150 \mathrm{~km}$, od granic Gdańska po okolice Karwi. Utworzone laboratorium podlegało kolejnym ministerstwom, w tym Rolnictwa oraz Przemysłu i Handlu. Laboratorium to, według dokumentu $z 1922$ r., wydanego przez Ministerstwo Byłej Dzielnicy Pruskiej (MBDP), miało zajmować się poznawaniem zasobów ryb w Bałtyku oraz miejsc połowów mogacych służyć polskim rybakom. Badano również czas i warunki tarła rzutujące na tempo wzrostu ryb. Zakres działań obejmował też studia nad metodami i technika połowów, opracowanie materiałów niezbędnych do wydawania ochronnych przepisów rybackich oraz teoretyczne badania w zakresie

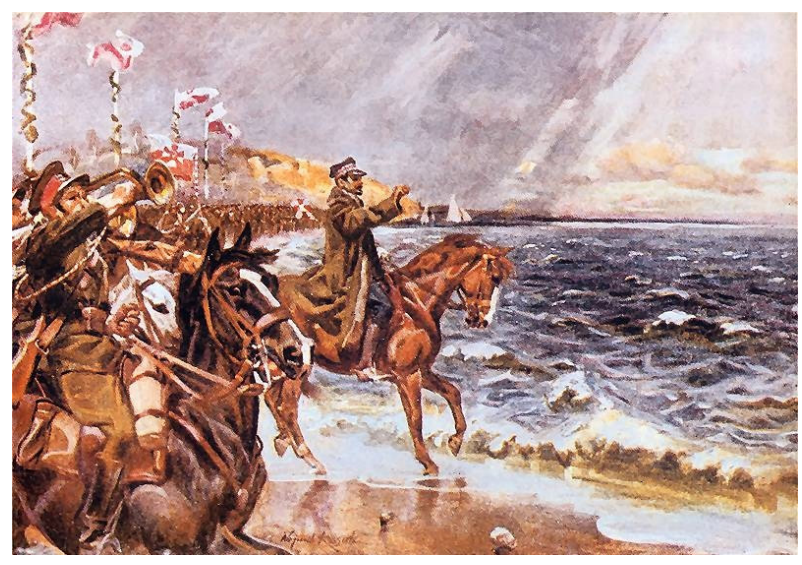

Ryc. 1. Obraz Zaślubin Polski z Bałtykiem - gen. Józef Haller w symbolicznym geście wrzuca pierścień w fale Zatoki Puckiej. Autor Wojciech Kossak, ilustracja $z$ http://www.pinakoteka.zascianek.pl/Kossak_W/Images/Zaslubiny_z_morzem.jpg

nauki o morzu, ściśle związane $z$ wiedzą rybacka.

Pierwszy, zorganizowany przez stację, rejs badawczy odbył się prawdopodobnie 9 maja 1923 r. na pokładzie kutra o nazwie "Tryton". Celem było złowienie młodocianych płastug w Zatoce Puckiej. Uczestniczył w nim Kazimierz Demel, pierwszy stały pracownik MLR, a towarzyszył mu ichtiolog Borys Dixon. W późniejszym czasie obaj badacze zgromadzili ogromny dorobek naukowy, uzyskali tytuły profesorów i międzyna-

Słowa kluczowe: bioróżnorodność, Morski Instytut Rybacki - Państwowy Instytut Badawczy, zbieranie danych, ichtiofauna, monitoring Morza Bałtyckiego

*Artykuł powstał dzięki wsparciu finansowemu z projektu POPC.02.03.01-00-0081/19 „Integracja i mobilizacja danych o różnorodności biotycznej Eukaryota w zasobach polskich instytucji naukowych" (IMBIO) (Joanna Całkiewicz) oraz Wieloletniego Programu Zbierania Danych Rybackich na lata 2014-2020; źródło finansowania: Program Operacyjny „Rybactwo i Morze" dla priorytetu 3-działanie 3.2 Gromadzenie danych (Ireneusz Wójcik). 


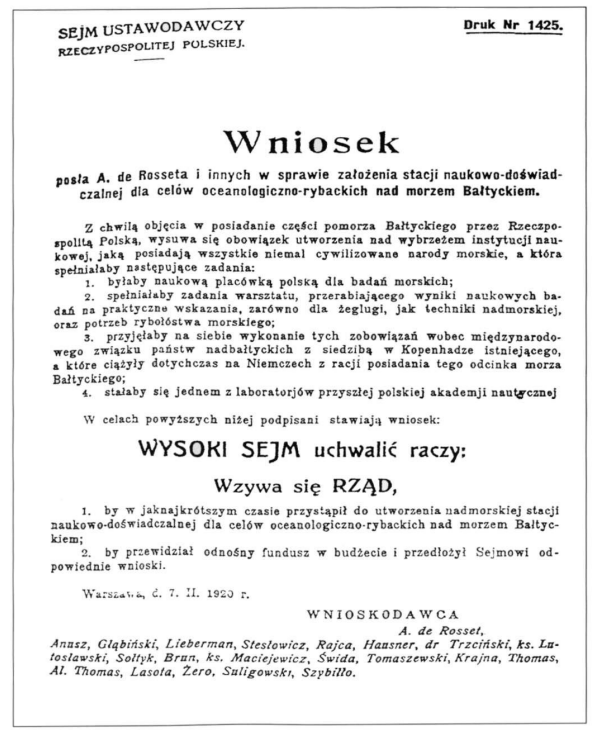

Ryc. 2. Druk sejmowy z 7 lutego 1920 r. zawierający wniosek posłów i działaczy w sprawie założenia stacji naukowo-doświadczalnej dla celów oceanologiczno-rybackich nad morzem Bałtyckim (za ROPELEWSKIM 2001).

rodowe uznanie. Morskie Laboratorium Rybackie organizowało również kursy biologii morza oraz gościło stypendystów i naukowców $z$ różnych ośrodków w kraju (Ryc. 3). W 1924 r. ukazały się pierwsze publikacje poświęcone m.in. metodom i narzędziom połowowym stosowanym przez polskich rybaków morskich oraz ichtiofaunie południowego Bałtyku. Przykładowo, prace „Spis ryb Bałtyku Naszego" Demel (1925a) rozpoczal słowami: „Spis niniejszy obejmuje wszystkie, dotad stwierdzone na przestrzeni morza naszego, gatunki morskie, słodkowodne $i$ wędrowne". Następnie $\mathrm{w}$ tabeli umieścił 46 gatunków wraz $\mathrm{z}$ informacją o środowisku, stwierdzonym stanowisku i zakresie wystę-

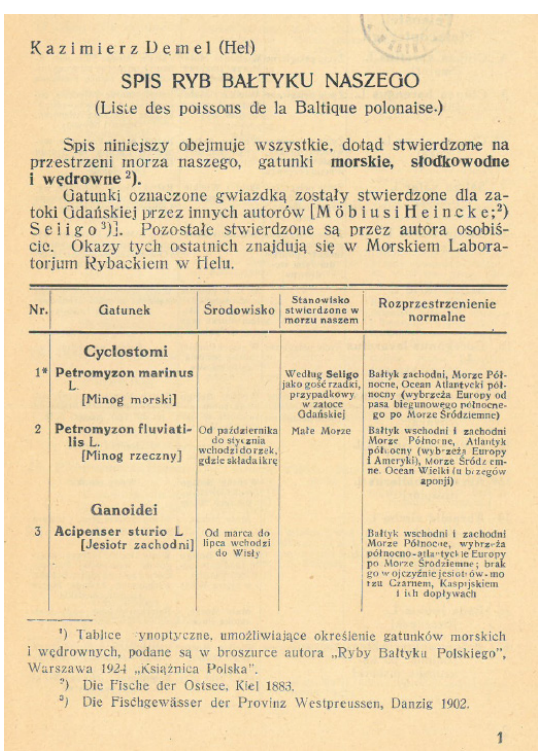

Ryc. 4. Pierwsza strona opracowania „Spis ryb Battyku Naszego" Kazimierza Demela z 1925 roku.

powania (Ryc. 4). W tym samym roku nieco później opisał (DEMEL 1925b) w broszurze: „Rzadki przybysz południowy $w$ morzu naszem" rybę, której nie ujął w wcześniejszym spisie. Był to okazały włócznik złowiony przy Kuźnicy przez rybaka Alojzego Budzisza. Okaz mierzył 2,3 m i ważył $57 \mathrm{~kg}$ (Ryc. 5). W broszurce nadmieniono że: „Sadzac $z$ danych zebranych na wybrzeżu poraz to pierwszy schwytano gatunek ten $w$ naszych wlasnych (terytorjalnych) wodach. Dla tego też nie zostat on umieszczony $w$ moim "Spisie [...], choć $w$ Zatoce Gdańskiej był już od czasu do czasu poławiany [...]. W kościótku ewangelickim $w$ Helu znajduje sie jego głowa podarowana przez rybaków, pochodzaca jeszcze z czasów przedwojennych. W Batty-

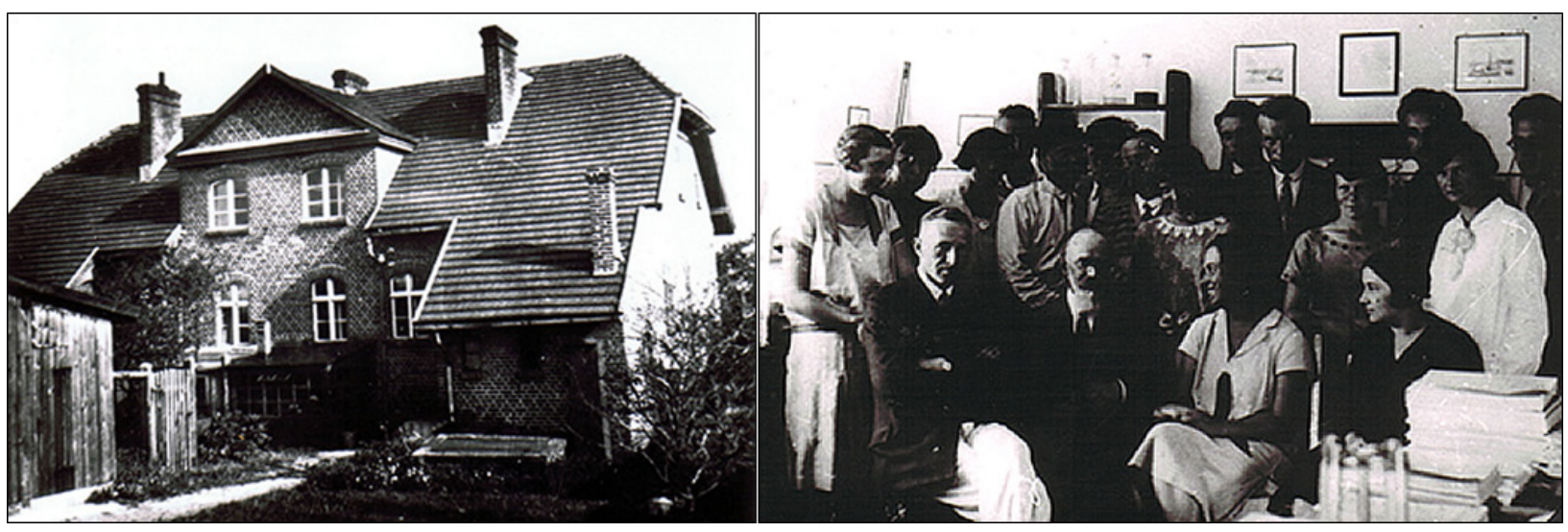

Ryc. 3. Budynek Morskiego Laboratorium Rybackiego na Helu (po lewej) oraz uczestnicy kursu biologii morza wraz z profesorem Kazimierzem Demelem i profesorem Michałem Siedleckim (po prawej), lipiec 1929 (https://akwarium.gdynia.pl/historia-akwarium/). 


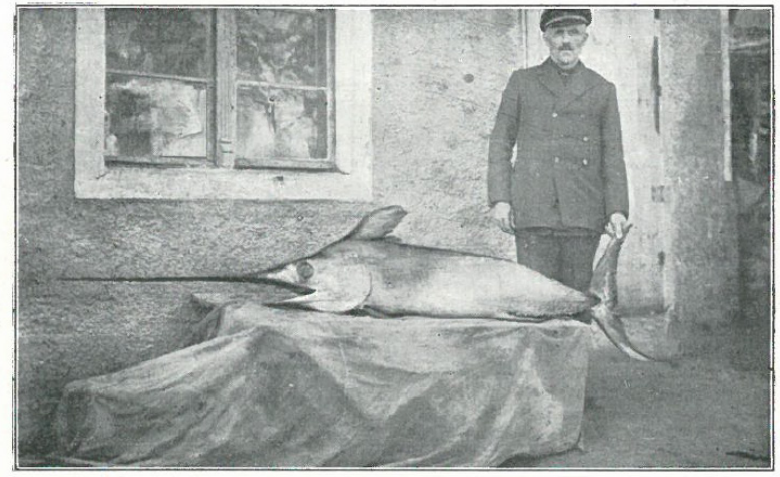

Xiphias gladius L. zlowiony dnia 16. IX. 1925 roku przy Kuźnicy w „Wielkiem Morzu”.

Ryc. 5. Zdjęcie $z$ oryginalnym podpisem $z$ broszury "Rzadki przybysz południowy $w$ morzu naszem” Kazimierza Demela z 1925 r.

ku włócznik widywany bywat aż po brzegi litewskie $i$ finskie, zawsze jednak pojedynczo jako przybysz rzadki, raczej zabłakany. Również rzadkim jest $w$ Bałtyku Zachodnim i Morzu Pótnocnem". Jest duża szansa, że opisany miecznik znajduje się w którymś $z$ warszawskich muzeów. W notatce dodano, że ze względu na zaporową cenę Laboratorium nie mogło sobie pozwolić na odkupienie okazu od rybaka, ale "okaz został zakupiony przez pewna pania $z$ zamiarem ofiarowania go jednemu $z$ muzeów przyrodniczych $w$ Warszawie". W innym opracowaniu (DEMEL 1925c) „Kilka uwag o warunkach życia $i$ rozmieszczeniu flonder (Pleuronectidae) $w$ wodach polskich Bałtyku" Kazimierz Demel porównał cztery gatunki fląder występujacych w Bałtyku (z ówcześnie 10 notowanych): „Flonderka - stornia (Pleuronectes flessus), flondra-szolka (Pl. Platessa), limanda przez

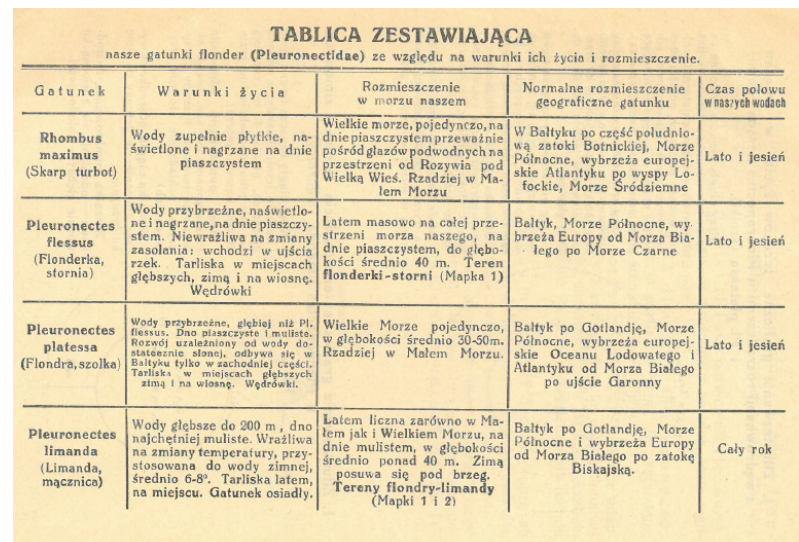

Ryc. 6. Oryginalna tabela porównująca warunki życia oraz rozmieszczenie 4 gatunków ryb płaskich w Morzu Bałtyckim.

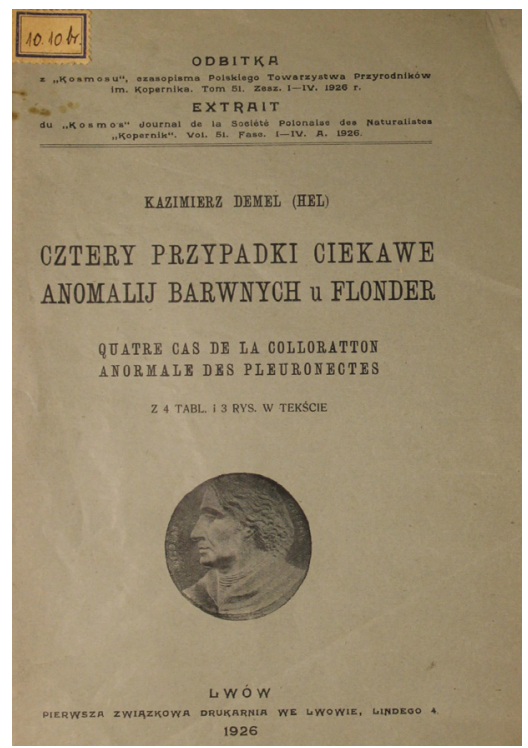

Ryc. 7. Okładka odbitki z „Kosmosu” z 1926 r.

Kaszubów nazywana macznica i skarp-turbot (Rhombus maximus)". Podsumowanie przedstawiono $\mathrm{w}$ tabeli (Ryc. 6). Jedno $\mathrm{z}$ opracowań dotyczace fląder ${ }^{1}$ oraz ich anomalii barwnych zostało umieszczone $\mathrm{w}$ zeszycie Kosmosu $(51,1926)$ (Ryc. 7), a tytuł brzmiał: „Cztery przypadki ciekawe anomalij barwnych u Flonder" (DEMEL 1926). Artykuł rozpoczynajacy się słowami: „W kolekcjach bałtyckich Morskiego Laboratorjum Rybackiego w Helu znajduje się cały szereg okazów flonder, anormalnie ubarwionych, wszystkie pochodza z wód naszego morza, dostarczone do laboratorium przez rybaków helskich $w$ ciagu dwóch sezonów letnich 1923 i 1924", zawiera bardzo szczególowy opis ubarwień flądry wraz z 4 tablicami (Ryc. 8). Opis kończy się słowami: „W notatce niniejszej, któ-

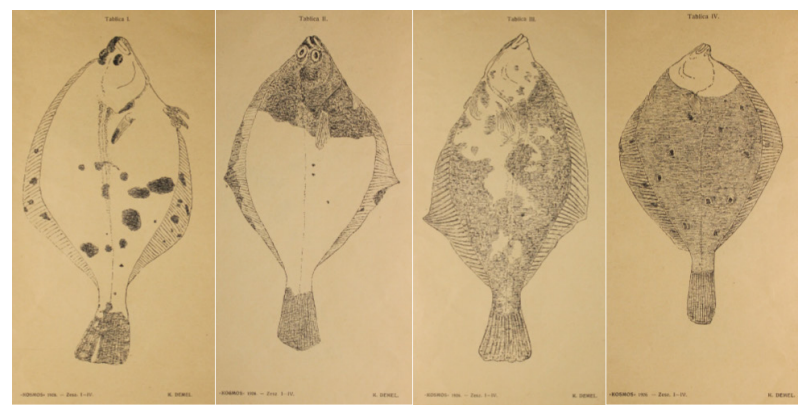

Ryc. 8. Cztery ryciny przedstawiajace anomalie w ubarwieniu flądry (wg DEMEL 1926).

${ }^{1}$ Flądra - ogólna nazwa ryby płastugokształtnej, charakteryzującej się spłaszczonym, asymetrycznym ciałem. Dawniej ta nazwa określano ryby z rodzaju Pleuronectes w rodzinie flądrowatych, obecnie często jeszcze jest odnoszona do storni (dawniej Pleuronectes flesus, obecnie Platichthys flesus), nazywanej również fląderką (źródło: https://pl.wikipedia.org/wiki/Fl\%C4\%85dra). 


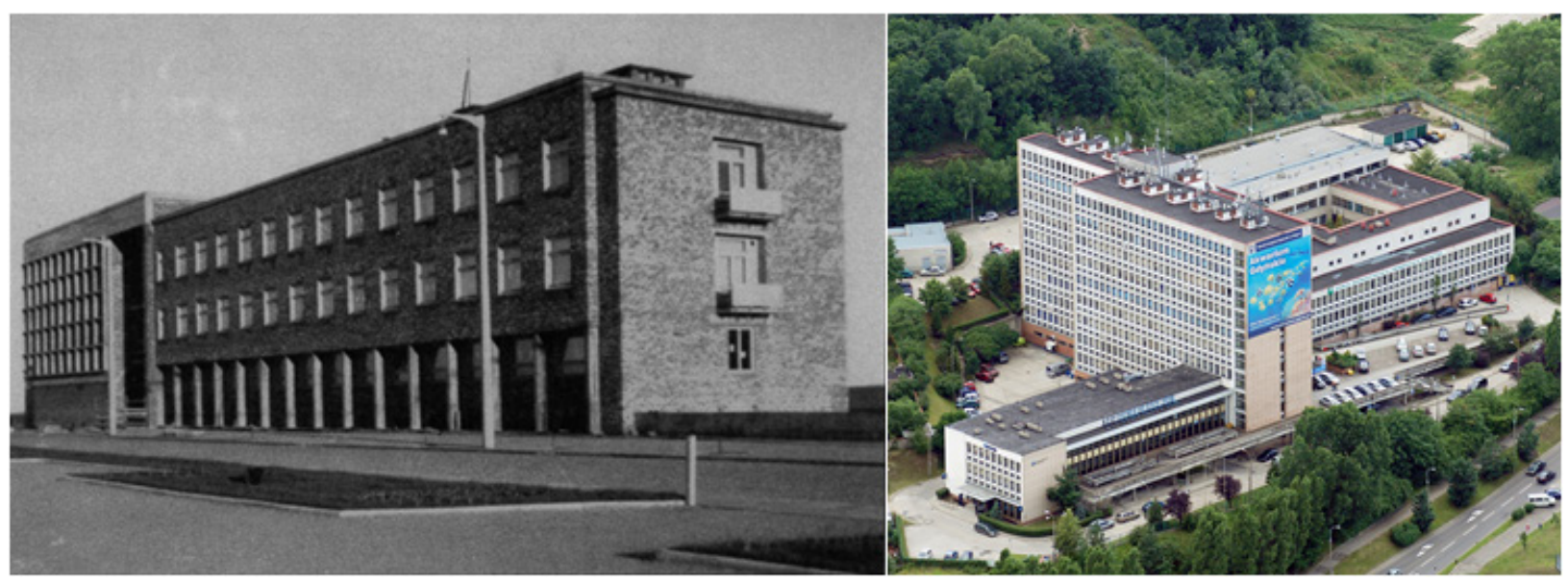

Ryc. 9. Budynek Akwarium, lata 30. (po lewej) oraz obecna siedziba Morskiego Instytutu Rybackiego (po prawej).

rej zadaniem jest tylko przedstawienie czterech osobliwych przypadków anomalij barwnych u flonder, nie możemy wdawać się $w$ zawite kwestie determinizmu tych anomalij, wiążcych się $z$ zagadnieniem pochodzenia fląder - ryb wogóle monstrualnych". W połowie 1931 r. Instytut Bałtycki w Toruniu opublikował ocenę osiagnięć i dorobku MLR (patrz RoPELEWSKI 2001): „W okresie ośmiu lat istnienia wyszły $z$ tego zakładu 44 prace dotyczace nie tylko zagadnień zwiazanych ze sprawami rybactwa morskiego, lecz dotyczace też szeregu zasadniczych kwestii $z$ dziedziny biologii morza, $w$ szczególności stosunków przyrodniczych na polskim Battyku. Ustality one skład gatunkowy naszej ichtiofauny morskiej, szacujac go na 51 gatunków, przeprowadzity analize zoogeograficzna $i$ biologiczna tej ichtiofauny, opisaty niektóre metody połowu stosowane przez naszych rybaków morskich, wreszcie dały dokładny zarys terenów połowu $w$ naszych wodach terytorialnych, zilustrowany na mapkach, opartych na dokładnych obserwacjach dokonanych na podstawie objazdów po morzu $i$ wywiadu $z$ rybkami. Zwrócono sie potem do badania zespołów dennych, wyróżnienia ich składu, ilościowego wystepowania, $w$ uzależnieniu od naturalnych warunków $i$ charakteru podłoża, który taki decydujacy wpływ wywiera na ugrupowanie zespołów dennych. Można $z$ cała pewnościa powiedzieć, że większość wiadomości ogólnych odnośnie stosunków biologicznych panujacych na naszym morzu czerpie przyrodnik polski $z$ wyniku badań oraz publikacji wychodzacych $z$ zakładu morzoznawczego w Helu".

Wracając do losów placówek zajmujących się badaniami morskimi, kolejnym istotnym wydarzeniem dla badań morza i rybołówstwa w Polsce było utworzenie w Warszawie w 1928 r. stowarzyszenia pod nazwa Morski
Instytut Rybacki. Prezesem zarzadu stowarzyszenia był prof. Michał Siedlecki, wybitny zoolog z Uniwersytetu Jagiellońskiego w Krakowie. Natomiast w 1932 r. utworzono Morska Stację na Helu, która przejęła prace Morskiego Laboratorium Rybackiego. Dyrektorem i organizatorem został prof. Mieczysław Bogucki. Sześć lat później placówkę przeniesiono do Gdyni, do nowej siedziby wybudowanej na końcu Mola Południowego (obecne Akwarium Gdyńskie) (Ryc. 9). Po wojnie reaktywowano jednostke pod pierwotną nazwą. W tym samym czasie wznowiło również działalność stowarzyszenie „Morski Instytut Rybacki" podporzadkowane Ministerstwu Żeglugi. W 1949 r. nastapiło włączenie Morskiego Laboratorium Rybackiego do Morskiego Instytutu Rybackiego $z$ siedzibą w Gdyni. Od poczattku istnienia Instytut zwiazany jest $z$ rybołówstwem morskim, a głównym jego zadaniem jest prowadzenie prac naukowo-badawczych w tym zakresie. Szczegółowa historia powstania MIR-u i jego działalności do 2001 r. została opisana przez ROPELEWSKIEGO (2001).

Już przed druga wojna światowa pracownicy MIR zajmowali się poszukiwaniem bogatych łowisk dla rybołówstwa polskiego, co zaowocowało m.in. poszerzeniem tradycyjnych obszarów połowów o rejon wokół Bornholmu. Po wojnie naukowcy wraz $z$ flota ruszyli na Morze Północne, Morze Barentsa i dalej, na łowiska nowej Fundlandii, Labradoru, Afryki, Pacyfiku, Antarktyki i Antarktydy (KRZEPTOWSKI 2006). Statki badawcze Instytutu: „Wieczno”, „Profesor Siedlecki” i „Profesor Bogucki” współpracujące $z$ flotą rybacka, docierały w najdalsze rejony oceanów, odkrywając nowe łowiska. Więcej o polskim rybołówstwie dalekomorskim można przeczytać w książce „Pół wieku i trzy oce- 


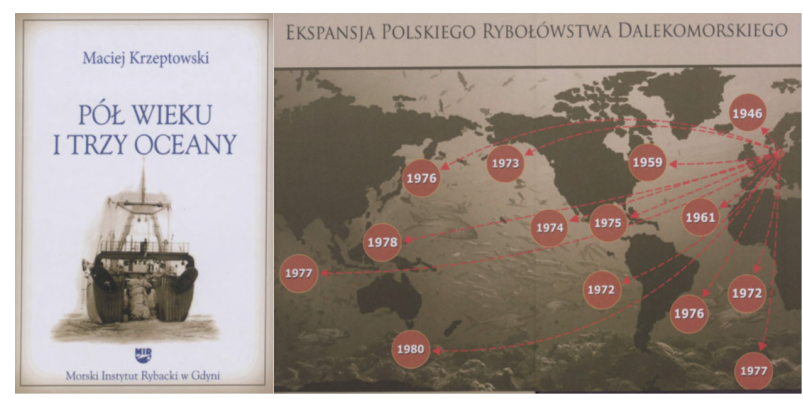

Ryc. 10. Ilustracja przedstawiająca ekspansję polskiego rybołówstwa dalekomorskiego wg książki Macieja Krzeptowskiego „Pół wieku i trzy oceany”.

any" (KRZEPTOWSKI 2006) (Ryc. 10), wydanej z okazji 85-lecia powstania MIR-u.

$\mathrm{Na}$ początku października 1964 r. w MIR utworzono nową, samodzielną komórkę $\mathrm{w}$ pionie naukowym - Ośrodek Zwiadów Rybackich. Jego zadaniem było organizowanie i kierowanie tzw. operatywnym zwiadem rybackim, czyli poszukiwaniem łowisk prowadzonym przez statki łowcze, wydzielane w tym celu przez przedsiębiorstwa połowowe. W tym czasie rozpoczęto również bardziej systematyczny monitoring ichtiofauny w Bałtyku. Nabyte po ponad 40 latach doświadczenia ułatwily sprostanie nowym zadaniom wynikajacym $z$ przystapienia Polski do Unii Europejskiej. Morski Instytut Rybacki stał się jednostka odpowiedzialną za polski wkład do unijnego wieloletniego programu zbioru danych rybackich, poczatkowo EFDC (ang. European Fisheries Data Collection), a obecnie DCF (ang. Data Collection Framework). Unijny wieloletni program zbioru danych rybackich (WPZDR) został w postaci programów narodowych zapoczatkowany przez państwa członkowskie w 2001 r. Wraz z przystapieniem Polski do Unii Europejskiej, polskie rybołówstwo morskie zostało objęte wspólna polityka rybacka UE oraz unijnym programem zbierania danych rybackich. Polska realizuje Unijny program zbioru danych nieprzerwanie od 2005 r. Obecnie operacja gromadzenia danych, zarzadzania nimi i ich wykorzystania w sektorze rybołówstwa oraz wspieranie doradztwa naukowego w zakresie wspólnej polityki rybołówstwa jest realizowana w ramach Europejskiego Funduszu Morskiego i Rybackiego oraz krajowego Programu Operacyjnego „Rybactwo i Morze” dla priorytetu 3 - działanie 3.2. Gromadzenie danych. Celem programu krajowego jest rozwój biologicznych i ekonomicznych baz danych rybackich. Programy krajowe sa koordynowane i wspierane finansowo przez UE.

Monitoring na mniejsza skalę, realizowany od momentu powstania MIR, szczególnie od czasu utworzenia Ośrodka Zwiadów
Rybackich, a następnie poprzez mniejsze, statutowe projekty, został rozwinięty i dostosowany do wymogów UE określających międzynarodowa metodyke zbioru i opracowania prób. Informacje zbierane $\mathrm{w}$ ramach DCF wynikaja $z$ regulacji prawnych UE: Rozporzadzenie Parlamentu Europejskiego $i$ Rady (UE) 2017/1004 z dnia 17 maja 2017 roku ${ }^{2}$, Decyzja Wykonawcza Komisji (UE) 2019/909 z dnia 18 lutego 2019 roku $^{3}$ oraz Decyzja Delegowana Komisji (UE) 2019/910 $z$ dnia 13 marca 2019 roku (wersje aktualne na kwiecień 2021). Regulacje te definiuja zakres danych rybackich podlegajacych gromadzeniu oraz zasady ich zbioru. Dane liczbowe poukładane sa $\mathrm{w}$ moduły wymagajace zebrania danych o: strukturze i zdolnościach połowowych floty rybackiej, nakładzie połowowym oraz wynikach ekonomicznych jednostek rybackich, grup jednostek rybackich, a także informacji $z$ zakładów przetwórstwa rybnego, jak również danych: biologicznych $\mathrm{z}$ morskiego rybołówstwa komercyjnego i rekreacyjnego, o wynikach rejsów badawczych wykonywanych dla oceny stanu zasobów - wielkości połowów ryb poszczególnych gatunków, a także $z$ analiz ichtiologicznych $\mathrm{w}$ zakresie niezbędnym dla wykonania oceny stanu zasobów metodami analitycznymi (np.: rozkłady długości ryb, wiek, płeć, dojrzałość płciowa, masa osobnicza, stopień wypełnienia żoładka, ocena stanu zdrowotnego). Zakres pozyskiwania danych, zgodnie z wytycznymi wspólnej polityki rybackiej UE, jest stopniowo poszerzany o nowe moduly umożliwiające zastosowanie na większa skalę modelowania ekosystemowego i bioekonomicznego dla oceny stanu zasobów rybnych i zarzadzania nimi (Grzebielec, sprawozdanie wewnętrzne, 2006).

Programy krajowe podlegaja ocenie i akceptacji Komisji Europejskiej. Państwa członkowskie, które realizuja programy, sa zobowiazane do składania Rocznych Rapor-

${ }^{2}$ Rozporzadzenie Parlamentu Europejskiego i Rady (UE) Nr 2017/1004 z dnia 17 maja 2017 roku w sprawie ustanowienia unijnych ram gromadzenia danych, zarzadzania nimi i ich wykorzystywania w sektorze rybołówstwa oraz w sprawie wspierania doradztwa naukowego w zakresie wspólnej polityki rybołówstwa oraz uchylajace rozporzadzenie Rady (WE) nr 199/2008 (Dz.U. L 157 z 20.6.2017, s. 1),

${ }^{3}$ Decyzja Wykonawcza Komisji (UE) 2019/909 z dnia 18 lutego 2019 roku ustanawiajaca wykaz obowiazkowych połowów kontrolnych oraz progi na potrzeby wieloletniego unijnego programu gromadzenia danych i zarzadzania nimi w sektorze rybołówstwa i akwakultury (Dz.U. L $145 \mathrm{z}$ 4.6.2019, s. 21)

${ }^{4}$ Decyzja Delegowana Komisji (UE) 2019/910 z dnia 13 marca 2019 roku ustanawiajaca wieloletni program Unii dotyczacy gromadzenia danych biologicznych, środowiskowych, technicznych i społeczno-ekonomicznych oraz zarzadzania nimi w sektorze rybołówstwa i akwakultury(Dz.U. L 145 z 4.6.2019, s. 27) 
tów podlegajacych prawnemu wymogowi akceptacji i zatwierdzania przez KE, w oparciu o ocenę dokonywaną przez niezależne Grupy Ekspertów Naukowego, Technicznego i Ekonomicznego Komitetu Rybackiego KE (STECF). Dane te stanowia podstawę dla prowadzenia przez Komisję Europejska i Departamenty Rybackie państw członkowskich racjonalnego, przejrzystego i odpowiedzialnego monitoringu oraz zarządzania rybołówstwem na obszarach morskich UE.

Dane ekonomiczne sa wykorzystywane do opracowania analiz przygotowywanych na zamówienie STECF, Wspólnotowe Centrum Badawcze (ang. Joint Research Center, JRC) oraz innych odbiorców, w tym Departamentu Rybołówstwa ministerstwa właściwego do spraw rybołówstwa, natomiast biologiczne programy zbioru danych sa koordynowane przez Międzynarodową Radę Badań Morza (ICES). Zgromadzone informacje biologiczne sa wykorzystywane przez grupy robocze ICES zajmujace się ocenami stanu zasobów rybnych. Ocena stanu zasobów eksploatowanych stad ryb, dokonywana w oparciu o dane zbierane w ramach WPZDR, stanowi podstawę analiz i decyzji administracyjnych w zakresie zarzadzania rybołówstwem, wydawanych w formie przepisów prawnych, w tym między innymi przepisów ustanawiających środki ochrony zasobów (np. wymiary ochronne ryb, okresy i rejony zakazu połowów, dozwolone rozmiary oczek w sieciach rybackich, konstrukcja narzędzi połowowych) oraz poziom dopuszczalnej eksploatacji poszczególnych stad ryb w postaci corocznych kwot połowowych.

\section{SPOSOBY POZYSKIWANIA MATERIAŁÓW DO ZBIORÓW}

Podstawowym narzędziem badawczym jest statek badawczy r/v Baltica (Ryc. 11) wraz ze swoimi urzadzeniami do analiz różnorodności biotycznej środowisk morskich. Co roku odbywaja się dwa rejsy badawcze typu BITS (Baltic International Trawl Survey), odpowiednio w I i IV kwartale roku, $\mathrm{z}$ wykorzystaniem standaryzowanego badawczego włoka dennego - zgodnie $z$ międzynarodowym programem koordynacyjnym, opracowanym przez grupę roboczą Międzynarodowej Rady Badań Morza. Celem rejsów jest uzyskanie wskaźników rekrutacji, liczebności oraz rozmieszczenia dorszy i ryb płaskich, a także ich parametrów biologicznych, na tle danych środowiskowych. Corocznie realizowane sa również dwa badawcze rejsy hydroakustyczne: w maju - rejs BASS (ang. Baltic Acoustic Sprat Survey), we wrześniu/ październiku - rejs BIAS (ang. Baltic International Acoustic Survey). Ich celem jest

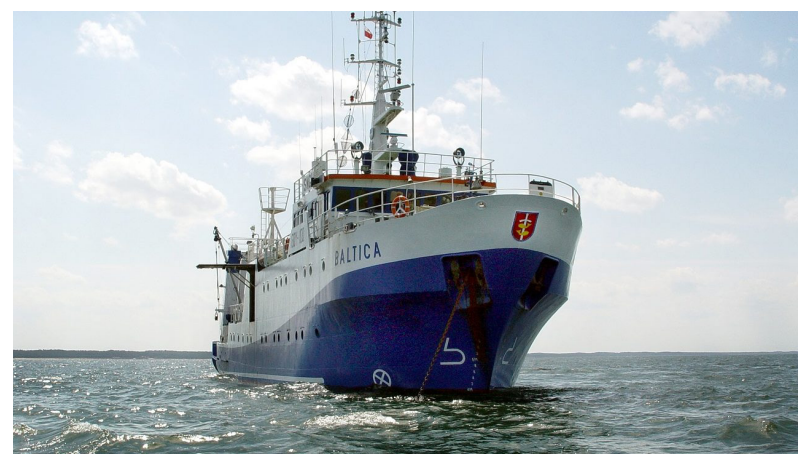

Ryc. 11. Statek badawczy $\mathrm{r} / \mathrm{v}$ Baltica (źródło: https://mir.gdynia.pl/rv-baltica/).

określenie stanu zasobów i rozmieszczenia przestrzennego stada śledzi, szprotów i dorszy w toni wodnej Polskich Obszarów Morskich $\mathrm{w}$ rejonie Południowego Bałtyku, przy zastosowaniu metody przegladów akustycznych (sondaż hydroakustyczny uzupełniony o połowy kontrolne), na tle parametrów środowiskowych. We wszystkich tych rejsach badawczych rejestrowane sa również dane meteorologiczne i hydrologiczne, jak np.: pomiary fizycznych parametrów wody morskiej obejmujace temperature, zasolenie i zawartość tlenu w lokalizacjach połowu ryb oraz na standardowych stacjach hydrograficznych profilu głównego południowego Bałtyku, dla każdej jednometrowej warstwy wody od powierzchni do dna. Plany takich rejsów sa w pełni koordynowane na całym Bałtyku. Wszystkie rejsy badawcze państw bałtyckich odbywaja się w tym samym czasie i pokrywają możliwie cały obszar występowania ryb danego gatunku. Każde państwo ma określony obszar badań podczas danego rejsu. W ten sposób uzyskuje się „fotografię" sytuacji danego stada, jak również występujących wtedy warunków hydrologicznych.

Wszystkie statki badawcze stosuja te same standaryzowane narzędzia połowowe. Zbierane sa dane dotyczące wydajności połowu, składu gatunkowego, wielkościowego, wagi, stanu gonad, zawartości żołądków oraz szeregu innych parametrów. Każdorazowo $\mathrm{w}$ trakcie rejsu badaniom podlega kilka tysięcy ryb, a część $z$ nich jest mrożona do dalszych badań na lądzie.

Drugim $z$ podstawowych źródeł pozyskiwania danych biologicznych sa informacje pozyskiwane przez specjalistów - obserwatorów naukowych w trakcie rejsów komercyjnych na jednostkach rybackich (Ryc. 12). Umożliwia to zbiór danych dotyczących operacji połowowych oraz danych biologicznych ryb wszystkich poławianych gatunków, w tym zwłaszcza gatunków limitowanych $z$ uwzględnieniem różnych łowisk i segmentów floty, a także narzędzi połowowych. W trak- 


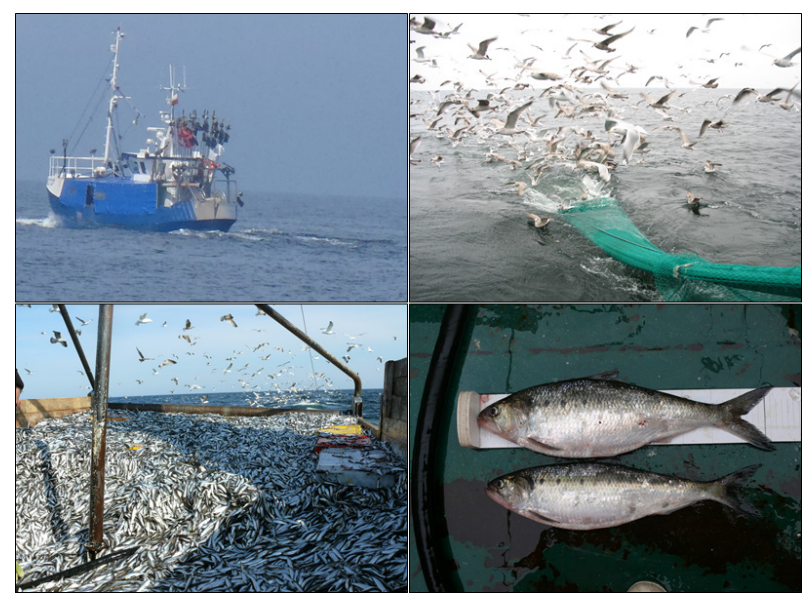

Ryc. 12. Przykład rejsów komercyjnych na jednostkach rybackich (autor: Wojciech Deluga).

cie rejsów zbierane sa także dane odnośnie wydajności połowu, składu gatunkowego i wielkościowego złowionych ryb oraz przyłowu. Część zebranych prób jest zabezpieczana do dalszych szczegółowych analiz ichtiologicznych na lądzie. Programem objęte jest również rybołówstwo rekreacyjne (Ryc. 13).

Kolejnym sposobem pozyskiwania danych sa wyprawy do portów i przystani, gdzie pobierane sa losowo próby ryb bezpośrednio $z$ wyładunków $z$ kutrów. Tu również zbierane sa wszystkie podstawowe dane, podobnie jak na jednostkach rybackich. Dodatkowo, szereg danych rybackich zbieranych jest w trakcie realizacji wielu projektów badawczych MIR z zakresu monitoringu ichtiologiczno-środowiskowego.

Wszystkie dane zgromadzone w trakcie realizacji unijnego wieloletniego programu zbioru danych rybackich sa opracowywane w laboratoriach MIR i wprowadzane do elektronicznej bazy danych. Dodatkowym i niezbędnym źródłem informacji odnośnie aktywności połowowej floty rybackiej, wydajności połowowych, składu gatunkowego połowów, czy rodzaju stosowanych narzędzi w układzie czasowo-przestrzennym, sa dane $z$ obowiąkowych raportów dostarczanych przez jednostki do Centrum Monitorowania Rybołówstwa (Wydział Departamentu Rybo-

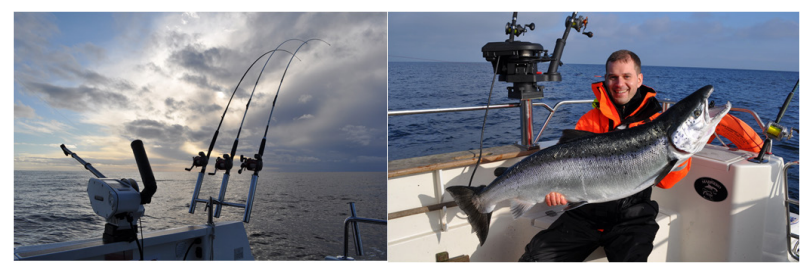

Ryc. 13. Przykład rybołówstwa rekreacyjnego metoda trollingu (po lewej) oraz złowiony łosoś - 113 cm, 14,5 kg (po prawej) (autorzy: Adam Lejk i Łukasz Dziemian). łówstwa Ministerstwa Rolnictwa i Rozwoju Wsi).

Dane biologiczne w określonym i ustandaryzowanym formacie sa przekazywane przez MIR oraz instytuty pozostałych państw bałtyckich, m.in. do regionalnej bazy danych obsługiwanej przez Międzynarodowa Radę Badań Morza (ICES) w Kopenhadze. Organizacja ta, bazując na swym ponadstuletnim doświadczeniu $\mathrm{w}$ badaniach morza, zajmuje się oceną stanu zasobów ryb i doradztwem naukowym na potrzeby zarządzania rybołówstwem.

Dla zobrazowania stopnia zaangażowania Instytutu i skali działań $\mathrm{w}$ ramach realizacji wieloletniego programu zbioru danych rybackich (corocznie), poza wymienionymi czterema rejsami badawczymi $\mathrm{r} / \mathrm{v}$ Baltica, pozyskiwane sa dane o rozkładzie długości łowionych ryb, masie osobniczej, płci, wieku, dojrzałości płciowej oraz inne parametry wraz $z$ wielkością połowów i odrzutów. Pochodza one $z$ ponad 200 rybackich rejsów komercyjnych na Bałtyku (próby zbierane w morzu w trakcie rejsów i $z$ wyładunków w krajowych portach bałtyckich) oraz kilku rejsów dalekomorskich na wodach poza bałtyckich (np. Morze Barentsa, Południowo-Wschodni Pacyf i w rejon Północno-Zachodniej Afryki), a także z 20-22 rejsów na jednostkach prowadzacych rekreacyjne połowy dorszy bałtyckich oraz dane $z$ rejestrów Kapitanatów i Bosmanatów portów i przystani rybackich, dotyczace skali rybołówstwa rekreacyjnego (morskie rejsy wędkarskie). Warto dodać, że corocznie w realizację WPZDR zaangażowanych jest ok. 80-90 pracowników Instytutu. Wykonuje się pomiary długości od 110 do 157 tys. ryb różnych gatunków występujacych w połowach (liczba obserwowanych gatunków ryb, zależnie od roku, wynosi od 50 do 80) oraz szczegółowe analizy ichtiologiczne (określenie długości, masy, płci, wieku, stopnia dojrzałości, odżywiania itp.), którym poddawanych jest od 15 do 25 tys. ryb różnych gatunków. Tabele 1, 2 przedstawiaja liczby ryb poddanych badaniom w ramach WPZDR w ostatnich pięciu latach, $z$ podziałem na próby zebrane $z$ bałtyckiego rybołówstwa komercyjnego oraz w trakcie bałtyckich rejsów badawczych realizowanych z udziałem r/v Baltica (zestawienie nie obejmuje prób ryb zbieranych $\mathrm{w}$ trakcie rejsów dalekomorskich - poza obszarem M. Bałtyckiego). W 2020 r., ze względu na ograniczaniem zwiazane $z$ COVID-19, zbiór danych rybackich był względnie niewielki.

Od 2005 r. w elektronicznej bazie danych rybackich MIR zarejestrowano łacznie 153 gatunki ryb stwierdzonych w połowach komercyjnych i badawczych. Szczegółowej analizie ichtiologicznej (określenie długości, 
Tabela 1. Liczebność ryb poddanych badaniom $\mathrm{w}$ ramach WPZDR $\mathrm{w}$ ostatnich pięciu latach w oparciu o rejsy komercyjne.

\begin{tabular}{|c|c|c|c|c|c|c|c|c|c|c|}
\hline \multicolumn{11}{|c|}{ Próby z rejsów komercyjnych - Bałtyk } \\
\hline \multirow{2}{*}{ Gatunek } & \multicolumn{5}{|c|}{ Pomiary długości (w szt.) } & \multicolumn{5}{|c|}{ Analizy szczegółowe (w szt.) } \\
\hline & 2016 & 2017 & 2018 & 2019 & 2020 & 2016 & 2017 & 2018 & 2019 & 2020 \\
\hline dorsze & 15593 & 11773 & 9814 & 6326 & 230 & 2986 & 2402 & 1812 & 1900 & 47 \\
\hline śledzie & 12845 & 18073 & 5252 & 7851 & 8902 & 3731 & 3358 & 1406 & 2185 & 2655 \\
\hline szproty & 13998 & 16636 & 8973 & 12366 & 6523 & 3271 & 3425 & 2272 & 3429 & 1997 \\
\hline stornie & 7338 & 5913 & 3982 & 5600 & 3941 & 1867 & 1017 & 671 & 1220 & 755 \\
\hline inne & 6915 & 7214 & 5158 & 5052 & 7761 & 2444 & 1973 & 984 & 1587 & 1973 \\
\hline Razem & $56 \quad 689$ & 59609 & $33 \quad 179$ & 37195 & 27357 & 14299 & $12 \quad 175$ & 7145 & 10321 & 7427 \\
\hline $\begin{array}{l}\text { liczba gatunków } \mathrm{w} \\
\text { pozycji inne }\end{array}$ & 36 & 31 & 33 & 35 & 37 & 13 & 12 & 7 & 10 & 12 \\
\hline
\end{tabular}

Tabela 2. Liczebność ryb poddanych badaniom w ramach WPZDR w ostatnich pięciu latach w oparciu o rejsy badawcze.

\begin{tabular}{|c|c|c|c|c|c|c|c|c|c|c|}
\hline \multicolumn{11}{|c|}{ Próby z rejsów badawczych - Bałtyk } \\
\hline \multirow{2}{*}{ Gatunek } & \multicolumn{5}{|c|}{ Pomiary długości (w szt.) } & \multicolumn{5}{|c|}{ Analizy szczegółowe (w szt.) } \\
\hline & 2016 & 2017 & 2018 & 2019 & 2020 & 2016 & 2017 & 2018 & 2019 & 2020 \\
\hline dorsze & 20805 & 26109 & 17680 & 22906 & 19648 & 1082 & 1508 & 1613 & 1727 & 1076 \\
\hline śledzie & 20242 & 29825 & 25653 & 25133 & 23969 & 3032 & 3651 & 3470 & 3307 & 3042 \\
\hline szproty & 15929 & 27662 & 23921 & 25956 & 25440 & 1571 & 2605 & 2103 & 2001 & 1993 \\
\hline stornie & 9182 & 13717 & 10281 & 13176 & 10712 & 1612 & 1848 & 1848 & 1713 & 1479 \\
\hline inne & 3240 & 6269 & 5638 & 4596 & 3549 & 1593 & 1715 & 1375 & 1361 & 1010 \\
\hline Razem & 69398 & 103582 & $83 \quad 173$ & 91767 & 83318 & 8890 & 11327 & 10409 & 10109 & 8600 \\
\hline $\begin{array}{l}\text { liczba gatunków w } \\
\text { pozycji inne }\end{array}$ & 27 & 25 & 25 & 29 & 23 & 22 & 16 & 15 & 19 & 14 \\
\hline
\end{tabular}

masy, płci, wieku, dojrzałości płciowej, stopnia wypełnienia żołąlka i innych parametrów, zależnie od gatunku) poddano 271800 ryb, a u 1900000 osobników przeprowadzono pomiary długości.

Od 2017 r. prowadzone sa w ramach WPZDR również badania monitoringowe ryb dwuśrodowiskowych (węgorzy, troci i łososi) w wodach śródlądowych Polski. Podstawowe informacje odnoszace się do podstaw prawnych, zakresu gromadzonych danych, stosowanej metodyki, międzynarodowej koordynacji i wyników realizacji WPZDR można znaleźć na stronie: https://dcf.mir.gdynia.pl/.

Zestawienie najczęściej obserwowanych gatunków w połowach i wyładunkach komercyjnych monitorowanych przez obserwatorów zostało przedstawione w Tabeli 3. Zestawienie to obejmuje projekt WPZDR $z$ wyłaczaniem prób zbieranych $\mathrm{w}$ trakcie rejsów dalekomorskich.
Innym wieloletnim projektem badawczym prowadzonym w MIR od 2011 r. jest monitoring ichtiofauny w polskich obszarach morskich. Realizowany jest w ramach Państwowego Monitoringu Srodowiska (PMŚ) na zlecenie Głównego Inspektoratu Ochrony Środowiska. Program monitoringu został zaprojektowany w celu zwiększenia wiedzy o zjawiskach zachodzacych w Bałtyku dla potrzeb podejmowania działań na rzecz ochrony tego ekosystemu w zakresie ichtiofauny. Wyniki prowadzonych badań pozwalaja na ocenę stanu środowiska wód morskich i ocenę stanu ekologicznego (lub potencjału ekologicznego) jednolitych części wód przejściowych i przybrzeżnych na podstawie pomiarów obejmujących: określenie masy i liczebności ryb innych gatunków niż przemysłowe (w tym gatunki obce/inwazyjne) w każdym połowie oraz analize ichtiologiczna reprezentatywnej próby, uwzględniającą: długość, masę osobniczą, płeć, stadium rozwoju gonad, stopień 
Tabela 3. Najczęściej obserwowane gatunki w połowach i wyładunkach komercyjnych w ramach projektu WPZDR (zestawienie nie obejmuje prób ryb zbieranych w trakcie rejsów dalekomorskich, uszeregowane od najliczniejszych).

\begin{tabular}{|c|c|c|}
\hline Nazwa polska & Nazwa łacińska & Nazwa angielska \\
\hline Dorsz & Gadus morhua Linnaeus, 1758 & Baltic Atlantic cod \\
\hline Śledź & Clupea harengus Linnaeus, 1758 & Baltic herring \\
\hline Szprot & Sprattus sprattus (Linnaeus, 1758) & European sprat \\
\hline Stornia & Platichthys flesus (Linnaeus, 1758) & European flounder \\
\hline Okoń & Perca fluviatilis Linnaeus, 1758 & European perch \\
\hline Łosoś atlantycki & Salmo salar Linnaeus, 1758 & Atlantic salmon \\
\hline Leszcz & Abramis brama (Linnaeus, 1758) & Freshwater bream \\
\hline Węgorz & Anguilla anguilla (Linnaeus, 1758) & European eel \\
\hline Sandacz & Sander lucioperca (Linnaeus, 1758) & Pike-perch \\
\hline $\mathrm{P} \square$ loć & Rutilus rutilus (Linnaeus, 1758) & Roach \\
\hline $\mathrm{G} \square$ adzica & Pleuronectes platessa Linnaeus, 1758 & European plaice \\
\hline Troć wędrowna & Salmo trutta Linnaeus, 1758 & Sea trout \\
\hline Turbot & Scophthalmus maximus (Linnaeus, 1758) & Turbot \\
\hline Jazgarz & Gymnocephalus cernuus (Linnaeus, 1758) & Ruffe \\
\hline Witlinek & Merlangius merlangus (Linnaeus, 1758) & Whiting \\
\hline Babka bycza & Neogobius melanostomus (Pallas, 1814) & Round goby \\
\hline Tobiasz & Ammodytes tobianus Linnaeus, 1758 & Small sandeel \\
\hline Dobijak & Hyperoplus lanceolatus (Le Sauvage, 1824) & Launce / Greater sandeel \\
\hline Krap & Blicca bjoerkna (Linnaeus, 1758) & White bream \\
\hline Ciosa & Pelecus cultratus (Linnaeus, 1758) & Saberfish \\
\hline Kur diabeł & Myoxocephalus scorpius (Linnaeus, 1758) & Short-horn scorpion \\
\hline Karaś srebrzysty & Carassius gibelio (Bloch, 1782) & Prussian carp \\
\hline Leszcz & Abramis brama (Linnaeus, 1758) & Freshwater breams nei \\
\hline Belona pospolita & Belone belone (Linnaeus, 1760) & Garfish \\
\hline Certa & Vimba vimba (Linnaeus, 1758) & Vimba bream \\
\hline Tasza & Cyclopterus lumpus Linnaeus, 1758 & Lumpfish \\
\hline Sieja & Coregonus lavaretus (Linnaeus, 1758) & European whitefish \\
\hline Makrela & Scomber scombrus Linnaeus, 1758 & Atlantic mackerel \\
\hline Stynka & Osmerus eperlanus (Linnaeus, 1758) & European smelt \\
\hline Lin & Tinca tinca (Linnaeus, 1758) & Tench \\
\hline Miętus & Lota lota (Linnaeus, 1758) & Burbot \\
\hline Ukleja & Alburnus alburnus (Linnaeus, 1758) & Bleak \\
\hline Aloza & Alosa fallax (Lacépede, 1803) & Shads \\
\hline Boleń & Leuciscus aspius (Linnaeus, 1758) & Asp \\
\hline Wzdręga & Scardinius erythrophthalmus (Linnaeus, 1758) & Rudd \\
\hline Motela & Enchelyopus cimbrius (Linnaeus, 1766) & Fourbeard rockling \\
\hline Jaź & Leuciscus idus (Linnaeus, 1758) & Ide/Orfe \\
\hline Cierniczek & Pungitius pungitius (Linnaeus, 1758) & Ninespine stickleback \\
\hline Ciernik & Gasterosteus aculeatus Linnaeus, 1758 & Three-spined stickleback \\
\hline Czarniak & Pollachius virens (Linnaeus, 1758) & Saithe \\
\hline
\end{tabular}


wypełnienia żołądka oraz wiek ryb. Dodatkowo poddaje się analizie parametry fizyko-chemiczne, niezbędne na potrzeby wyznaczania i testowania wskaźników oceniających stan środowiska wód. Badania te sa wykonywane na podstawie metodyki zawartej w „Podreczniku do monitoringu elementów biologicznych $i$ klasyfikacji stanu ekologicznego wód powierzchniowych. Aktualizacja metod", wydanym $\mathrm{w}$ ramach Biblioteki Monitoringu Środowiska w 2020 r. (https://www.gios. gov.pl/pl/aktualnosci/716-nowy-podrecznikdo-monitoringu-biologicznych-elementowjakosci-wod). W trakcie projektu wystawiono prawie 1500 sieci oraz wykonano 50 zaciagów, a analizie poddano 167000 ryb. Obecnie program monitoringu ichtiofauny $\mathrm{w}$ wodach morskich wykonywany jest zgodnie $z$ "Aktualizacja programu monitoringu wód morskich" opracowana przez GIOŚ (https:// rdsm.gios.gov.pl/images/projekt-aktualizacji-PMWM.pdf) i przedłożona do Komisji Europejskiej w 2021 r. Szczegółowy program badań opiera się na połowach w poszczególnych strefach Morza Bałtyckiego: płytkowodnej morza otwartego (Zatoka Pomorska, Ławica Słupska, Ławica Odrzana), głębokomorskiej morza otwartego (Basen Bornholmski, Wschodni Basen Gotlandzki oraz Basen Gdański) oraz w jednolitych częściach wód: przejściowych (Zalew Wiślany, Zalew Pucki, Zatoka Pucka Zewnętrzna, Zatoka Gdańska Wewnętrzna, Ujście Wisły Przekop, Zalew Szczeciński, Zalew Kamieński) i przybrzeżnych (polskie wody przybrzeżne Basenu Gotlandzkiego, Półwysep Hel, polskie wody przybrzeżne Basenu Bornholmskiego, wody przybrzeżne Zatoki Pomorskiej). Jednym z osiagnięć tych badań jest opracowanie, testowanie i rozwój multimetrycznego indeksu ryb do oceny stanu ekologicznego wód przejściowych (SMOLIŃSKI i CAEKIEWICZ 2015, CAEKIEWICZ i współaut. 2020). Zgodnie $z$ Ramowa Dyrektywa Wodna ${ }^{5}$ ichtiofauna traktowana jest jako jeden $z$ elementów biologicznych, monitorowanych w celu oceny jakości środowiska wodnego. Wpływ człowieka na środowisko Bałtyku może powodować zmiany $\mathrm{w}$ strukturze tego zgrupowania. Zatem wartości skonstruowanego wskaźnika powinny odzwierciedlać poziom antropopresji jakiej podlegaja ryby. W modelowaniu, jako wskaźnik skumulowanej presji antropogenicznej, zastosowany został tzw. Baltic Sea Impact Index (KORPINEN i współaut. 2012, HELCOM 2018). Wskaźnik ten bierze pod uwage głównie wpływ zanieczyszczenia wód

${ }^{5}$ Ramowa Dyrektywa Wodna (Dyrektywa 2000/60/WE Rady i Parlamentu Europejskiego z dnia 23 października 2000 r.) (Dz. Urz. WE 327 z 22.12.2000). biogenami i substancjami szkodliwymi oraz presję rybacką na różne elementy ekosystemu morskiego. Oprócz wyznaczenia szeregu wskaźników jakości wód w polskich obszarach morskich, MIR zapewnia dane, obsługe merytoryczna oraz konsultacje dokumentacji $\mathrm{w}$ zakresie monitoringu i oceny stanu ichtiofauny projektów HELCOM ${ }^{6}$, a także bierze udział $\mathrm{w}$ warsztatach roboczych organizowanych przez Komisję Europejska, dotyczacych takich cech jak: bioróżnorodność, łańcuchy troficzne, komercyjne gatunki ryb i skorupiaków, gatunki obce oraz poziom substancji zanieczyszczajacych $\mathrm{w}$ tkankach mięśniowych ryb bałtyckich.

Rezultaty tych prac sa wykorzystane przez GIOŚ i udostępnione organom administracji dla potrzeb planowania działań na rzecz ochrony zasobów ichtiofauny, zgodnie $z$ wymaganiami Konwencji o ochronie środowiska morskiego obszaru Morza Bałtyckiego $(\mathrm{HELCOM})^{7}$ z 1992 r., Ramowej Dyrektywy Wodnej oraz Ramowej Dyrektywy w sprawie Strategii Morskiej ${ }^{8}$, a także dla potrzeb zapewnienia współpracy międzynarodowej i informowania społeczeństwa.

Instytut uczestniczy również $\mathrm{w}$ badaniach środowiska morskiego, niezbędnych do przygotowania Oceny Oddziaływania na Środowisko planowanych na morzu inwestycji, takich jak morskie farmy wiatrowe czy rurociagi podmorskie. W ramach procesu przygotowania takich inwestycji prowadzona jest inwentaryzacja przyrodnicza w rejonie przewidzianym pod budowę. Znajomość składu gatunkowego ichtiofauny pozwala na wytypowanie najbardziej wrażliwych podmiotów oddziaływania inwestycji oraz ocenę zagrożeń, jakie niosa one dla ekosyste$\mathrm{mu}$ morskiego. Oprócz przedstawionego tu zakresu działań zwiazanych $z$ rybactwem i danymi ichtiologicznymi, MIR wykonuje także inne prace badawczo-rozwojowe. Dotycza one takich elementów fauny i flory jak: fitoplankton i zooplankton, makrozoobentos, meiobentos, makrofity, bakterie, czy pasożyty ryb. Prowadzone sa również badania w zakresie technologii przetwórstwa, oceny wartości odżywczej surowców i produktów

${ }^{6}$ Komisja Ochrony Środowiska Morskiego Bałtyku, znana również jako Komisja Helsińska- organizacja międzynarodowa proklamowana przez tzw. Konwencję helsińską z 1974 roku jako jej organ wykonawczy.

${ }^{7}$ Konwencja o ochronie środowiska morskiego obszaru Morza Bałtyckiego, sporzadzona w Helsinkach $z$ dnia 9 kwietnia 1992 r. (Dz. U. z 2000 r. Nr 28, poz. 346).

${ }^{8}$ Ramowa Dyrektywa w sprawie Strategii Morskiej (Dyrektywa Komisji 2017/845/UE z dnia 17 maja 2017 r. zmieniająca Dyrektywę 2008/56/WE Rady i Parlamentu Europejskiego $z$ dnia 17 czerwca 2008 r.) (Dz. Urz. UE L 164 z 25.06.2008, str. 19). 
rybołówstwa, ekonomiki rybackiej, czy rozwoju narzędzi rybackich. Przykładem tego ostatniego jest opracowanie w Zakładzie Zasobów Rybackich selektywnego worka dorszowego o oczku obróconym o 90, zwanego workiem T90. Przyrzad ten został wprowadzony rozporządzeniem Komisji Europejskiej w grudniu 2005 r. jako standardowe selektywne narzędzie do stosowania w rybołówstwie Morza Bałtyckiego.

Częścia MIR jest Akwarium Gdyńskie, którego misja jest prezentowanie gatunków zwierzat wodnych $z$ całego świata, a także przekazywanie wiedzy o środowisku wodnym. Akwarium podejmuje działania na rzecz ochrony zwierzat oraz propaguje idee jej ochrony, głównie poprzez edukację ekologiczna: prezentacje multimedialne, zajęcia laboratoryjne, czy zajęcia terenowo-laboratoryjne dla zróżnicowanych grup, od przedszkolaków po młodzież klas średnich. Dodatkowo Akwarium prowadzi Klub Młodego Odkrywcy Mórz, gdzie dzieci i młodzież maja możliwość zdobywania wiedzy poprzez zabawy edukacyjne i okazję do bliższego poznania pracy akwarysty.

W ramach projektu IMBIO udostepniamy około 160000 rekordów danych dotyczących rozmieszczenia ryb, głównie $z$ lat 1992-1996 oraz około 80000 rekordów rozmieszczenia bentosu, fitoplanktonu i zooplanktonu, jak również ptaków czy pasożytów ryb (dane bieżace oraz dane historyczne).

$$
\text { Streszczenie }
$$

Pierwszą polska placówkę badań morza - Morskie Laboratorium Rybackie (MLR) w Helu powołano 100 lat temu, w czerwcu 1921 roku. Utworzone laboratorium zajmowało się badaniem zasobów ryb w Bałtyku oraz rozpoznawaniem miejsc połowów, mogących służyć polskiemu rybołówstwu. W 1949 roku nastapiło włączenie Morskiego Laboratorium Rybackiego do Morskiego Instytutu Rybackiego $z$ siedziba w Gdyni. Od poczattku istnienia Instytut jest zwiazany $z$ rybołówstwem morskim $i$ jego głównym zadaniem jest prowadzenie prac naukowo-badawczych w tym zakresie. Od 2005 roku monitoring rybacki został znacząco rozwinięty w związku $z$ przystąpieniem Polski do Unii Europejskiej. Polskie rybołówstwo morskie zostało objęte wspólną polityka rybacka UE oraz unijnym programem zbierania danych rybackich. Obecnie operacja gromadzenia danych, zarzadzania nimi i ich wykorzystania w sektorze rybołówstwa oraz wspierania doradztwa naukowego w zakresie wspólnej polityki rybołówstwa jest realizowana w ramach Europejskiego Funduszu Morskiego i Rybackiego oraz krajowego Programu Operacyjnego „Rybactwo i Morze”.

\section{LITERATURA}

CAlKIEWICZ J., MARGOŃSKI P., SMOliński S., DZIEMIAN Ł., SPICH K., 2020. Evaluation of the polish multimetric fish index (pmfi) for transitional waters. Raport MIR-PIB.

DEMEL K.,1925a. Spis ryb Battyku naszego. I tom. Archiwum Rybactwa Polskiego, Bydgoszcz.

DEMEL K.,1925b. Rzadki przybysz południowy $w$ morzu naszem. I tom. Archiwum Rybactwa Polskiego, Bydgoszcz.

DEMEL K.,1925c. Kilka uwag o warunkach życia $i$ rozmieszczeniu flonder (Pleuronectidae) $w$ wodach polskich Battyku. I tom. Archiwum Rybactwa Polskiego, Bydgoszcz.

DEMEL K.,1926. Cztery przypadki ciekawe anomalij barwnych u flonder. Kosmos 51. Zesz. I-IV.

HelCOM, 2018. State of the Baltic Sea - Second HELCOM holistic assessment 2011-2016.

Baltic Sea Environment Proceedings 155.

KorPinen S., MESKi L., ANDERSEN J. H., LAAMANEN M., 2012. Human pressures and their potential impact on the Baltic Sea ecosystem. Ecol. Indic., doi:10.1016/j.ecolind.2011.09.023.

KRZEPTOWSKI, M., 2006. Pół wieku i trzy oceany. Morski Instytut Rybacki, Gdynia.

ROPELEWSKI A., 2001. Morski Instytut Rybacki: ludzie $i$ wydarzenia 1921-2001. Morski Instytut Rybacki, Gdynia.

SMOLIŃSKI S., CAŁKIEWICZ J., 2015. A fish-based index for assessing the ecological status of Polish transitional and coastal waters. Marine Pollut. Bull. 101, 497-506. 
KOSMOS Vol. 70, 2, 229-240, 2021

\author{
JoAnNa CAEKIEWICZ, IRENEusz WÓJCIK
}

National Marine Fisheries Research Institute, 1 Kotłataja Str., 81-332 Gdynia, E-mail: jcalkiewicz@mir.gdynia.pl

\title{
FISHERY AND ICHTHYOLOGICAL DATABSE OF THE NATIONAL MARINE FISHERIES RESEARCH INSTITUTE
}

The first Polish maritime research facility - the Sea Fisheries Laboratory (MLR) in Hel was established 100 years ago, in June 1921. The established laboratory dealt with the study of fish resources in the Baltic Sea and the identification of fishing grounds that could serve Polish fishermen. In 1949, the Sea Fisheries Laboratory was incorporated into the Sea Fisheries Institute in Gdynia. Since its inception, the Institute has been associated with sea fisheries and its main task is to conduct scientific and research work in this field. Since 2005, fisheries monitoring has been significantly developed in connection with Poland's accession to the European Union. Polish sea fisheries are covered by the EU common fisheries policy and the EU program of collecting fisheries data. Currently, the operation of the collection, management and use of data in the fisheries sector and support for scientific advice regarding the common fisheries policy is carried out under the European Maritime and Fisheries Fund and the national Operational Program „Fisheries and Sea”.

Keywords: biodiversity, Sea Fisheries Institute - National Research Institute, data collection, ichthyofauna, Baltic Sea monitoring 